\title{
Production and partial characterization of lipase from Penicillium verrucosum obtained by submerged fermentation of conventional and industrial media
}

\author{
Produção e caracterização parcial de lipase obtida por fermentação submersa de \\ Penicillium verrucosum utilizando meio convencional e industrial
}

\author{
Thaís da Luz Fontoura PINHEIRO ${ }^{1}$, Silvana MENONCIN ${ }^{1}$, Natália Molossi DOMINGUES ${ }^{1}$, \\ Débora de OLIVEIRA ${ }^{1 *}$, Helen TREICHEL ${ }^{1}$, Marco DI LUCCIO ${ }^{1}$, Denise Maria Guimarães FREIRE ${ }^{1}$
}

\begin{abstract}
The growing interest in lipase production is related to the potential biotechnological applications that these enzymes present. Current studies on lipase production by submerged fermentation involve the use of agro-industrial residues aiming at increasing economic attractiveness. Based on these aspects, the objective of this work was to investigate lipase production by Penicillium verrucosum in submerged fermentation using a conventional medium based on peptone, yeast extract, $\mathrm{NaCl}$ and olive oil, and an industrial medium based on corn steep liquor, Prodex Lac (yeast hydrolysate), $\mathrm{NaCl}$ and olive oil, as well as to characterize the crude enzymatic extracts obtained. Kinetics of lipase production was evaluated and the highest enzymatic activities, of 3.15 and $2.22 \mathrm{U} \cdot \mathrm{mL}^{-1}$, were observed when conventional and industrial media were used, respectively. The enzymatic extract showed optimal activity in the range from 30 to $40{ }^{\circ} \mathrm{C}$ and at $\mathrm{pH} 7.0$. Although the industrial medium presents economical advantages over the conventional medium, the presence of agro-industrial residues rich in nitrogen and other important nutrients seemed to contribute to a reduction in lipase activity.

Keywords: lipases; Penicillium verrucosum; submerged fermentation; partial characterization.
\end{abstract}

\section{Resumo}

O grande interesse atual na produção de lipases está relacionado às potenciais aplicações biotecnológicas que estas enzimas apresentam. Estudos relevantes referentes à produção de lipases por fermentação submersa envolvem o uso de resíduos agroindustriais objetivando diminuir o custo de produção do biocatalisador. Com base nestes aspectos, o objetivo deste trabalho foi investigar a produção de lipases por Penicillium verrucosum em fermentação submersa utilizando meio convencional (peptona, extrato de levedura, $\mathrm{NaCl}$ e óleo de oliva) e industrial (água de maceração de milho, Prodex Lac (hidrolisado de levedura), $\mathrm{NaCl}$ e óleo de oliva), bem como caracterizar parcialmente o extrato enzimático bruto obtido. A cinética de produção de lipases foi avaliada e as atividades enzimáticas mais elevadas $\left(3,15\right.$ e 2,22 U.mL $\left.\mathrm{mL}^{-1}\right)$ foram observadas quando o meio convencional e o meio industrial foram utilizados, respectivamente. O extrato enzimático mostrou atividade ótima no intervalo de 30 a $40{ }^{\circ} \mathrm{C}$ e em pH 7,0. Embora o meio industrial apresente vantagens econômicas sobre o meio convencional, a presença de resíduos agroindustriais ricos em nitrogênio e outros importantes nutrientes parece ter contribuído na obtenção de menores atividades enzimáticas.

Palavras-chave: lipases; Penicillium verrucosum; fermentação submersa; caracterização parcial.

\section{Introduction}

Lipases are enzymes belonging to the hydrolase group that has the main biological function of catalyzing the hydrolysis of insoluble triacylglycerols to generate free fatty acids, mono and diacylglycerols and glycerol. Besides their natural function, lipases can catalyze esterification, interesterification and transesterification reactions in non-aqueous media (HOUDE; KADEMI; LEBLANC, 2004; FREIRE, 1996). Microbial lipases are biocatalysts that have interesting characteristics, such as action under mild conditions, stability in organic solvents, high substrate specificity and regio-and enantioselectivity (SNELLMAN; SULLIVAN; COLWELL, 2002).
Recently, lipases assumed a prominent place in the world enzyme market, evidenced by an increase in the amount of information reported in literature, which contemplates an average of 1000 publications per year. After proteases and amylases, lipases are considered the third greatest group in sales volume, moving billions of dollars, showing their versatility of application, which makes them especially attractive for industrial applications (SNELLMAN; SULLIVAN; COLWELL, 2002; HASAN; SHAH; HAMEED, 2006; JAEGER; REETZ, 1998).

The potential for industrial applications of lipases comprises the industry of additives (flavor modification), fine chemistry

Recebido para publicação em 24/4/2007

Aceito para publicação em 14/9/2007 (002484)

${ }^{1}$ Laboratório de Biotecnologia de Alimentos, Departamento de Engenharia de Alimentos, Universidade Regional Integrada - URI, Campus de Erechim,

Av. Sete de Setembro, 1621, Centro, CEP 99700-000, Erechim - RS, Brasil, E-mail: odebora@uricer.edu.br

${ }^{*}$ A quem a correspondência deve ser enviada 
(ester synthesis), detergents (fat hydrolysis), wastewater treatment (decomposition and removal of oleaginous substances), leather (removal of fat from animal skin), pharmaceutical and the medical area (medicines, digestive aids and enzymes for diagnosis) (BURKERT, 2002; BURKERT; MAUGERI; RODRIGUES, 2004). However, the high production costs of these biocatalysts often restrict their use (SNELLMAN; SULLIVAN; COLWELL, 2002).

The use of agro-industrial residues as substrate in lipase production by submerged fermentation can significantly reduce the final price of the enzyme, and also add value to materials of low cost in the market (CASTILHO et al., 2000).

Thus, studies based on the use of different microorganisms, supplements and substrates for lipase production can contribute to finding ideal combinations for obtaining high value lipases, using substrates and operational conditions that facilitate the reduction of industrial scale production costs (VARGAS, 2004).

Based on these aspects, the objective of this work was to evaluate lipase production by submerged fermentation using Penicillium verrucosum as microorganism in conventional and industrial media, comparing process efficiency. The partial characterization of the crude enzymatic extracts from both fermentative media was carried out to study some of the properties of the lipases produced.

\section{Materials and methods}

\subsection{Cell production}

Penicillium verrucosum, used in the present study, was previously isolated by Freire (1996) from wastes of the babassu oil industry. This microorganism was maintained in glycerol and potato dextrose agar slants under refrigeration. The propagation of spores prior to fermentation was carried out for 7 days, at $27.5^{\circ} \mathrm{C}$, in a medium constituted of potato dextrose agar (PDA) $3.9 \%(\mathrm{~m} / \mathrm{v})$ and distilled water (VARGAS, 2004).

\subsection{Culture conditions}

Conventional media consisted of peptone, yeast extract, $\mathrm{NaCl}$ and olive oil in different concentrations. The industrial media contained corn steep liquor (CSL), yeast hydrolysate (Prodex $\mathrm{Lac}^{\circledast}$ ), $\mathrm{NaCl}$ and olive oil. Cultivation was carried out in $250 \mathrm{~mL}$ Erlenmeyer flasks covered with cotton plugs. The media $(100 \mathrm{~mL})$ were sterilized at $121^{\circ} \mathrm{C}$ for 15 minutes, cooled and inoculated with a suspension of spores to a final fixed count of $2 \times 10^{6}$ spores $/ \mathrm{mL}$. The effect of the volume of the spore suspension was evaluated according to the experimental design (Table 1). Samples were collected and filtered through Whatman qualitative paper. The filtrate was considered as crude enzyme and was used for analytical assays.

\subsection{Lipase activity}

Lipase activity was assayed by alkali titration using olive oil as substrate. Olive oil $(10 \% \mathrm{~m} / \mathrm{v})$ was emulsified with gum arabic $(5 \% \mathrm{~m} / \mathrm{v})$ in $100 \mathrm{mM}$ sodium phosphate buffer $\mathrm{pH}$ 7.0. A $2 \mathrm{~mL}$ sample of crude enzyme was added to $18 \mathrm{~mL}$ of this emulsion. After incubation in a shaker for 15 minutes at $37^{\circ} \mathrm{C}$ and $150 \mathrm{rpm}$, the reaction was interrupted and the fatty acids were extracted by the addition of $20 \mathrm{~mL}$ of an acetone/ethanol solution $(1: 1 \mathrm{v} / \mathrm{v})$. The amount of fatty acids liberated was then titrated with $0.05 \mathrm{M} \mathrm{NaOH}$ until $\mathrm{pH} 11$. Reaction blanks were run in the same way, but adding the sample after the addition of the acetone/ethanol solution. The lipase activities were performed in duplicate. A unit of lipase activity was defined as the amount of enzyme that liberates $1 \mu \mathrm{mol}$ of fatty acids per minute under the assay conditions Freire et al. (1997).

\subsection{Experimental design}

Process variables were evaluated in both conventional and industrial media using a Plackett-Burman (PB) experimental design with 12 experiments and 3 central points. Real and coded levels of the factors investigated in this work are presented in Table 1 . The response evaluated in all experiments was lipase activity.

After statistical analysis of the results obtained in the PB experimental design, a full $2^{2}$ factorial design was carried out for the conventional medium and a full $2^{3}$ factorial design for the industrial medium, for maximization of lipase production. Tables 2 and 3 present the variables and their levels of study for conventional and industrial media, respectively.

\subsection{Optimal temperature and $\mathrm{pH}$}

For determination of the optimum values of temperature and $\mathrm{pH}$ in terms of lipase activity, a full $2^{2}$ experimental design was performed using the crude enzymatic extracts obtained using conventional and industrial media. Sodium phosphate buffer at different $\mathrm{pH}$ was added to the emulsion for measurement of lipase activity and the samples were incubated in a shaker at different temperatures for 15 minutes and $150 \mathrm{rpm}$. The $\mathrm{pH}$ and temperature studied are presented in Table 4. The experiments were carried out in duplicates.

Table 1. Variables and levels studied in the PB experimental design of 12 experiments and 3 central points for lipase production by submerged fermentation using conventional and industrial media.

\begin{tabular}{ccccccc}
\hline Level & Temperature $\left({ }^{\circ} \mathrm{C}\right)$ & Inoculum $(\% \mathrm{~m} / \mathrm{v})$ & Peptone/CSL $(\% \mathrm{~m} / \mathrm{v})$ & Yeast extract/Prodex Lac $(\% \mathrm{~m} / \mathrm{v})$ & $\mathrm{NaCl}(\% \mathrm{~m} / \mathrm{v})$ & Olive oil $(\% \mathrm{~m} / \mathrm{v})$ \\
\hline-1 & 28 & 2.5 & 2 & 0.50 & 0.50 & 1.0 \\
$0^{*}$ & 32 & 7.5 & 5 & 8 & 1.75 & 1.75 \\
+1 & 36 & 12.5 & & 3.00 & 3.00 & 1.5 \\
\hline
\end{tabular}

${ }^{{ }^{*} \text { Central point. }}$ 
Table 2. Variables and levels studied in the full $2^{2}$ experimental design using the conventional medium.

\begin{tabular}{ccc}
\hline Level & Temperature $\left({ }^{\circ} \mathrm{C}\right)$ & Peptone $(\% \mathrm{~m} / \mathrm{v})$ \\
\hline-1 & 20 & 4 \\
$0^{*}$ & 28 & 8 \\
+1 & 36 & 12 \\
\hline
\end{tabular}

${ }^{*}$ Central point.

Table 3. Variables and levels studied in the full $2^{3}$ experimental design using the industrial medium.

\begin{tabular}{cccc}
\hline Level & Temperature $\left({ }^{\circ} \mathrm{C}\right)$ & CSL $(\% \mathrm{~m} / \mathrm{v})$ & Prodex Lac $(\% \mathrm{~m} / \mathrm{v})$ \\
\hline-1 & 20 & 4 & 2 \\
$0^{*}$ & 28 & 8 & 4 \\
+1 & 36 & 12 & 6 \\
\hline
\end{tabular}

${ }^{*}$ Central point.

Table 4. Variables and levels studied in the full $2^{2}$ experimental design for evaluation of optimal temperature and $\mathrm{pH}$.

\begin{tabular}{lcc}
\hline Level & Temperature $\left({ }^{\circ} \mathrm{C}\right)$ & $\mathrm{pH}$ \\
\hline-1.41 & 30 & 4.8 \\
-1 & 32 & 5.5 \\
$0^{*}$ & 37 & 7.0 \\
+1 & 42 & 8.5 \\
+1.41 & 44 & 9.1 \\
\hline
\end{tabular}

${ }^{*}$ Central point.

\section{Results and discussion}

\subsection{Lipase production using the conventional medium}

Table 5 presents the matrix of the $\mathrm{PB}$ experimental design of 12 experiments and 3 central points applied to the conventional medium and the lipase activity obtained at 48, 72 and 96 hours of fermentation.

An increase in the lipase activity after 96 hours of fermentation is observed in 8 of the 15 experiments. It is verified that higher lipase activity is obtained at $28^{\circ} \mathrm{C}$. Studies performed by Ellaiah et al. (2004) and Maia et al. (2001) for lipase production by fungi such as Aspergillus niger and Fusarium solani, respectively, also verified that the ideal temperature for the production of the enzyme was at $28^{\circ} \mathrm{C}$ for these microorganisms.

For a more consistent analysis of the results of this first experimental design, the data obtained at 96 hours of fermentation were tabulated and analyzed using the Statistica ${ }^{\circledR}$ software, in the Experimental Design module. We observed that, with a confidence of $95 \%$, temperature presented a negative effect on lipase production, while peptone concentration positively influenced lipase activity. The other variables were not significant, considering the same confidence level.

Based on the results obtained in the statistical analysis, we selected temperature and peptone concentration as the variables to be studied in a full $2^{2}$ design, to obtain the optimum lipase production in the conventional media. Since the concentration of yeast extract, $\mathrm{NaCl}$ and olive oil did not significantly influence lipase production, they were fixed at level -1 of the PB experimental design $(0.5 \% \mathrm{~m} / \mathrm{v}, 0.5 \% \mathrm{~m} / \mathrm{v}$ and $1 \% \mathrm{~m} / \mathrm{v}$, respectively). This result is economically interesting when scaling up is considered, since it may decrease the final cost of the enzyme (BURKERT, 2002). The results obtained in this $2^{2}$ experimental design are presented in Table 6 . The enzymatic activity profile can be better visualized in Figure 1 .

The best condition for lipase production by submerged fermentation using the conventional medium was obtained in run 1 of the $2^{2}$ factorial design $\left(20{ }^{\circ} \mathrm{C}, 7.5 \% \mathrm{v} / \mathrm{v}\right.$ inoculum, $4 \% \mathrm{~m} / \mathrm{v}$ peptone, $0.5 \% \mathrm{~m} / \mathrm{v}$ yeast extract, $0.5 \% \mathrm{~m} / \mathrm{v} \mathrm{NaCl}$ and $1 \% \mathrm{~m} / \mathrm{v}$ olive oil). The maximum lipase activity obtained in this design was $3.22 \mathrm{U} \cdot \mathrm{mL}^{-1}$, after 96 hours of fermentation (after the kinetic study), which is higher than that reported by Puthli et al. (2006), who evaluated lipase production by Candida rugosa, obtaining a maximum activity of $1.84 \mathrm{U} \cdot \mathrm{mL}^{-1}$ after 66 hours of fermentation. However, better results were found by Benjamin and Pandey (1995) (12.55 U.mL ${ }^{-1}$, after 72 hours of fermentation), also using Candida rugosa as microorganism.

\subsection{Lipase production using the industrial medium}

Table 7 presents the coded values and the responses for lipase activity obtained in the Plackett-Burman experimental design using the industrial media. The highest enzymatic activity was found after 72 hours in run $8\left(1.38 \mathrm{U} \cdot \mathrm{mL}^{-1}\right)$. This condition uses the lower levels of temperature, inoculum and olive oil concentration, and the higher levels of Prodex Lac and $\mathrm{NaCl}$ concentrations.

Similarly to the analysis of the first experimental design applied to the study with the conventional medium, statistical analysis of the results was carried out. We observed that all the variables were statistically significant $(p \leq 0.05)$. Concentrations of corn steep liquor, Prodex $\mathrm{Lac}$ and $\mathrm{NaCl}$ presented positive and significant effects, which indicates that a displacement of their concentration levels to higher values would lead to an increase in the values of enzymatic activity. The concentrations of oil, inoculum and the temperature showed a negative effect on lipase production. After analysis of the results, a full $2^{3}$ experimental design was carried out to evaluate the effect of temperature, corn steep liquor and Prodex Lac concentrations on lipase production. Inoculum concentration was fixed at the central point value of the $\mathrm{PB}$ experimental design $(7.5 \% \mathrm{~m} / \mathrm{v})$, as for the study performed with the conventional medium. Olive oil concentration, that presented a negative effect, was fixed at level $-1(1 \% \mathrm{~m} / \mathrm{v})$ and $\mathrm{NaCl}$ was maintained at level +1 . Table 8 presents the results of the $2^{3}$ factorial design. The results show an increase in lipase activities compared to the results obtained in the PB experimental design. These results are better visualized in Figure 2.

When using the industrial medium, the best condition found for lipase production by submerged fermentation was observed in run $5\left(20^{\circ} \mathrm{C}, 7.5 \% \mathrm{~m} / \mathrm{v}\right.$ inoculum, $4 \% \mathrm{~m} / \mathrm{v}$ corn steep liquor, $6 \% \mathrm{~m} / \mathrm{v}$ Prodex Lac, $3 \% \mathrm{~m} / \mathrm{v} \mathrm{NaCl}$ and $1 \% \mathrm{~m} / \mathrm{v}$ olive oil). Lipase activity presented a peak of maximum activity of about $2.63 \mathrm{U} \cdot \mathrm{mL}^{-1}$ after 72 hours of fermentation. This result is similar to that obtained by submerged fermentation using Aspergillus niger as microorganism (4 U.mL ${ }^{-1}$ ) (MAHADIK et al., 2004), but lower than that obtained in studies with Penicillium restrictum (13 U.mL ${ }^{-1}$ ) (FREIRE et al., 1997). 
Table 5. Matrix of the PB experimental design of 12 experiments and 3 central points (coded and real values) with the response lipase activity using the conventional medium.

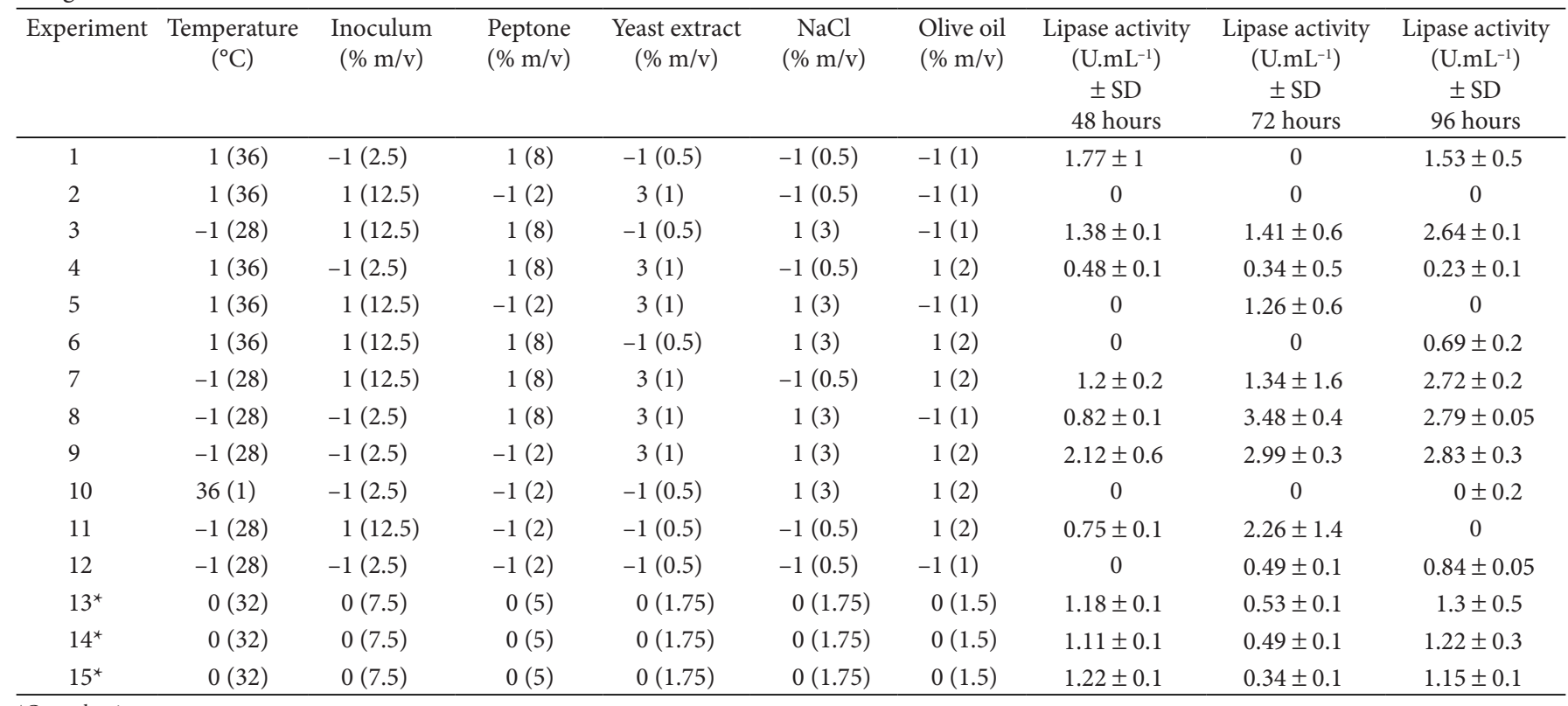

${ }^{\star}$ Central point.

Table 6. Matrix of the full $2^{2}$ experimental design (coded and real values) with the response lipase activity using the conventional medium.

\begin{tabular}{|c|c|c|c|c|c|}
\hline Experiment & $\begin{array}{c}\text { Temperature } \\
\left({ }^{\circ} \mathrm{C}\right)\end{array}$ & $\begin{array}{l}\text { Peptone } \\
(\% \mathrm{~m} / \mathrm{v})\end{array}$ & $\begin{array}{c}\text { Lipase activity } \\
\left(\mathrm{U}_{\mathrm{mL}}^{-1}\right) \\
48 \text { hours }\end{array}$ & $\begin{array}{c}\text { Lipase activity } \\
\left(\mathrm{U}_{\mathrm{mL}}^{-1}\right) \\
72 \text { hours }\end{array}$ & $\begin{array}{c}\text { Lipase activity } \\
\left(\mathrm{U}^{\left.-\mathrm{mL}^{-1}\right)}\right. \\
96 \text { hours }\end{array}$ \\
\hline 1 & $-1(20)$ & $-1(4)$ & 0 & 1.76 & 3.22 \\
\hline 3 & $-1(20)$ & $1(12)$ & 0 & 1.98 & 3.03 \\
\hline 4 & $1(36)$ & $1(12)$ & 0 & 0.82 & 0 \\
\hline $5^{*}$ & $0(28)$ & $0(8)$ & 0.61 & 0 & 0.15 \\
\hline $7^{*}$ & $0(28)$ & $0(8)$ & 2.38 & 0 & 0.15 \\
\hline
\end{tabular}

${ }^{*}$ Central point.

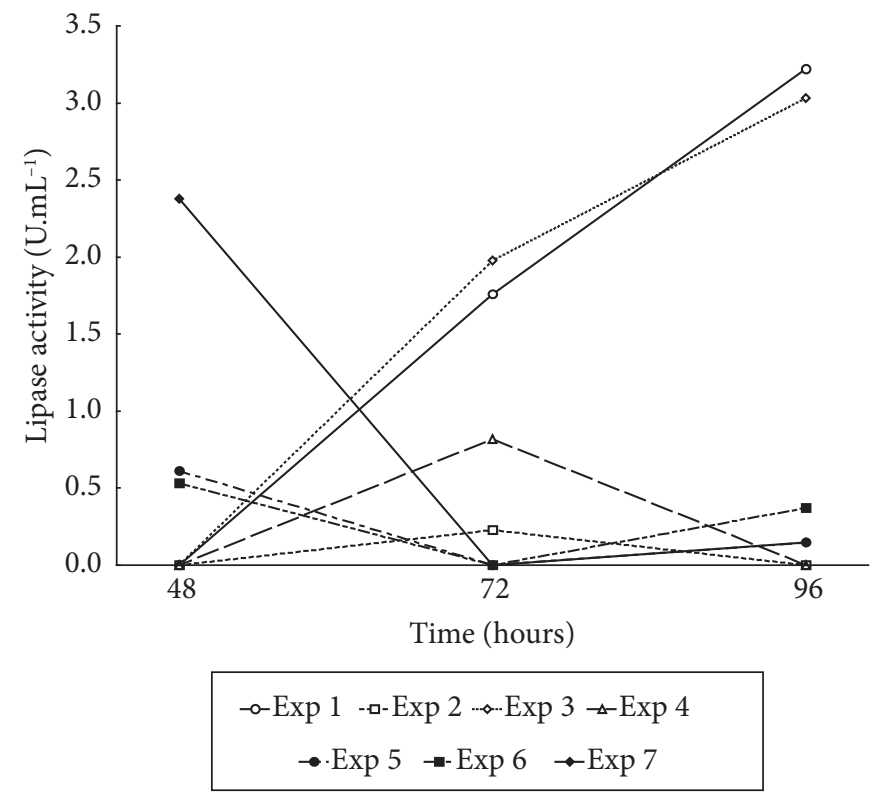

Figure 1. Kinetics of submerged fermentation for lipase production using the conventional medium: full $2^{2}$ experimental design.

\subsection{Characterization of the crude enzymatic extracts obtained using conventional and industrial media}

The determination of the optimal temperature and $\mathrm{pH}$ of the crude enzymatic extracts obtained by submerged fermentation was carried out through a $2^{2}$ full experimental design with 4 axial points and 3 central points. The experimental design and the results in terms of lipase activities are presented in Table 9, which shows that the highest lipase activities were 4.02 and $4.37 \mathrm{U} . \mathrm{mL}^{-1}\left(\mathrm{~T}=29.95^{\circ} \mathrm{C}\right.$ and $\left.\mathrm{pH} 7.0\right)$, corresponding respectively to runs 4 and 5. Tan et al. (2003) analyzed lipase production by submerged fermentation using Candida sp. and obtained $28^{\circ} \mathrm{C}$ and 7.0 as optimal temperature and $\mathrm{pH}$, respectively. The literature reports that in many cases neutral $\mathrm{pH}$ is generally defined as optimum for lipase activity (TAN et al., 2003; ABBAS et al., 2002; BURKERT, 2002; KAMINI et al., 1998; FADILOGLU; SOYLEMEZ, 1997; FREIRE et al., 1997; BENJAMIN; PANDEY, 2001).

The results of the partial characterization of the crude enzymatic extract obtained using the industrial medium can also be observed in Table 9. Runs 1, 8 and the central points led to the highest lipase activities. The temperature of $37^{\circ} \mathrm{C}$ and 
Table 7. Matrix of the PB experimental design of 12 experiments and 3 central points (coded and real values) with the response lipase activity using the industrial medium.

\begin{tabular}{|c|c|c|c|c|c|c|c|c|c|}
\hline Experiment & $\begin{array}{c}\text { Temperature } \\
\left({ }^{\circ} \mathrm{C}\right)\end{array}$ & $\begin{array}{c}\text { Inoculum } \\
(\% \mathrm{~m} / \mathrm{v})\end{array}$ & $\begin{array}{c}\text { CSL } \\
(\% \mathrm{~m} / \mathrm{v})\end{array}$ & $\begin{array}{c}\text { Prodex Lac } \\
(\% \mathrm{~m} / \mathrm{v})\end{array}$ & $\begin{array}{c}\mathrm{NaCl} \\
(\% \mathrm{~m} / \mathrm{v})\end{array}$ & $\begin{array}{l}\text { Olive oil } \\
(\% \mathrm{~m} / \mathrm{v})\end{array}$ & $\begin{array}{c}\text { Lipase activity } \\
\left(\mathrm{U}^{-\mathrm{mL}^{-1}}\right) \\
\pm \mathrm{SD} \\
48 \text { hours } \\
\end{array}$ & $\begin{array}{c}\text { Lipase activity } \\
\left(\mathrm{U}^{\left.-\mathrm{mL}^{-1}\right)}\right. \\
\pm \mathrm{SD} \\
72 \text { hours }\end{array}$ & $\begin{array}{c}\text { Lipase activity } \\
\left(\mathrm{U}^{\left.\mathrm{m} \mathrm{mL}^{-1}\right)}\right. \\
\pm \mathrm{SD} \\
96 \text { hours }\end{array}$ \\
\hline 2 & $1(36)$ & $1(12.5)$ & $-1(2)$ & $3(1)$ & $-1(0.5)$ & $-1(1)$ & $0.34 \pm 0.2$ & 0 & $0.65 \pm 0.4$ \\
\hline 3 & $-1(28)$ & $1(12.5)$ & $1(8)$ & $-1(0.5)$ & $1(3)$ & $-1(1)$ & $0.76 \pm 0.1$ & $0.19 \pm 0.2$ & 0 \\
\hline 4 & $1(36)$ & $-1(2.5)$ & $1(8)$ & $3(1)$ & $-1(0.5)$ & $1(2)$ & 0 & $0.84 \pm 0.3$ & $0.31 \pm 0.2$ \\
\hline 6 & $1(36)$ & $1(12.5)$ & $1(8)$ & $-1(0.5)$ & $1(3)$ & $1(2)$ & $0.07 \pm 0.1$ & 0 & 0 \\
\hline 7 & $-1(28)$ & $1(12.5)$ & $1(8)$ & $3(1)$ & $-1(0.5)$ & $1(2)$ & 0 & 0 & 0 \\
\hline 8 & $-1(28)$ & $-1(2.5)$ & $1(8)$ & $3(1)$ & $1(3)$ & $-1(1)$ & $0.34 \pm 0.1$ & $1.38 \pm 0.6$ & 0 \\
\hline 9 & $-1(28)$ & $-1(2.5)$ & $-1(2)$ & $3(1)$ & $1(3)$ & $1(2)$ & $0.49 \pm 0.2$ & 0 & 0 \\
\hline 10 & $36(1)$ & $-1(2.5)$ & $-1(2)$ & $-1(0.5)$ & $1(3)$ & $1(2)$ & 0 & 0.15 & $0.27 \pm 0.1$ \\
\hline $15^{*}$ & $0(32)$ & $0(7.5)$ & $0(5)$ & $0(1.75)$ & $0(1.75)$ & $0(1.5)$ & 0 & $0.19 \pm 0.05$ & $0.34 \pm 0.1$ \\
\hline
\end{tabular}

${ }^{*}$ Central point.

Table 8. Matrix of the full $2^{3}$ experimental design (coded and real values) with the response lipase activity using the industrial medium.

\begin{tabular}{|c|c|c|c|c|c|c|}
\hline Experiment & $\begin{array}{c}\text { Temperature } \\
\left({ }^{\circ} \mathrm{C}\right)\end{array}$ & $\begin{array}{c}\mathrm{CSL} \\
(\% \mathrm{~m} / \mathrm{v})\end{array}$ & $\begin{array}{c}\text { Prodex Lac } \\
(\% \mathrm{~m} / \mathrm{v})\end{array}$ & $\begin{array}{c}\text { Lipase activity } \\
\left(\mathrm{U}^{\left.-\mathrm{mL}^{-1}\right)}\right. \\
48 \text { hours }\end{array}$ & $\begin{array}{c}\text { Lipase activity } \\
\left(\mathrm{U}^{\left.-\mathrm{mL}^{-1}\right)}\right. \\
72 \text { hours }\end{array}$ & $\begin{array}{c}\text { Lipase activity } \\
\left(\mathrm{U}^{-\mathrm{mL}^{-1}}\right) \\
96 \text { hours }\end{array}$ \\
\hline 1 & $-1(20)$ & $-1(4)$ & $-1(2)$ & 0 & 0.31 & 0.47 \\
\hline 3 & $-1(20)$ & $1(12)$ & $-1(2)$ & 0.35 & 0 & 0 \\
\hline 4 & $1(36)$ & $1(12)$ & $-1(2)$ & 0 & 0 & 0.78 \\
\hline 5 & $-1(20)$ & $-1(4)$ & $1(6)$ & 0.08 & 2.63 & 0 \\
\hline 7 & $-1(20)$ & $1(12)$ & $1(6)$ & 1.23 & 0.03 & 0 \\
\hline 8 & $1(36)$ & $1(12)$ & $1(6)$ & 0 & 0 & 0.64 \\
\hline $9^{*}$ & $0(28)$ & $0(8)$ & $0(4)$ & 0 & 0.47 & 0.9 \\
\hline $10^{*}$ & $0(28)$ & $0(8)$ & $0(4)$ & 0 & 0.47 & 1.5 \\
\hline $11^{*}$ & $0(28)$ & $0(8)$ & $0(4)$ & 0 & 0.39 & 1.2 \\
\hline
\end{tabular}

${ }^{{ }^{*} \text { Central point. }}$

$\mathrm{pH} 7.0$ are the conditions of the central points and were also defined as optimal for the lipases obtained by Fadiloglu and Soylemez (1997) when using Candida sp. and by Burkert (2002), who characterized the crude enzymatic extract of Geotrichum candidum NRRL-Y552. In the same way, the lipase obtained by Penicillium restrictum has optimal temperature and $\mathrm{pH}$ at $37^{\circ} \mathrm{C}$ and 7.0, respectively (FREIRE et al., 1997). In a global evaluation, it can be noticed that optimal temperature for lipase is in the range from 30 to $40^{\circ} \mathrm{C}$, as it was verified by Abbas et al. (2002); Kolossvary (1996); Burkert (2002); Kamini et al. (1998); Fadiloglu and Soylemez (1997); Freire et al. (1997) and Benjamin and Pandey (2001). The optimal pH found in the present work is in agreement with the data presented by other authors, which is in the range of 5.0 to 9.0 (BURKERT, 2002; MAHADIK et al., 2004; FREIRE et al., 1997; TAN et al., 2003; ABBAS et al., 2002; KAMINI; MALA; PUVANAKRISHNAN, 1998; FADILOGLU; SOYLEMEZ, 1997; BENJAMIN; PANDEY, 2001; MARTINS,
2001; KOLOSSVÁRY, 1996; SHU; XU; LIN, 2006; PASTORE; DA COSTA; KOBLITZ, 2003).

\section{Conclusions}

The use of submerged fermentation for lipase production using conventional and agro-industrial residues as substrates presented satisfactory results. The microorganism Penicillium verrucosum produced up to $3.22 \mathrm{U} \cdot \mathrm{mL}^{-1}$ of lipase in 96 hours of fermentation with the conventional medium and $2.63 \mathrm{U} \cdot \mathrm{mL}^{-1}$ in 72 hours of fermentation when using the industrial medium.

Although maximum lipase activity with the industrial medium was lower than that obtained with the conventional medium, we should consider the low costs of industrial media, which would improve process economics.

It is important to point out that neither corn steep liquor nor Prodex Lac can be considered as exclusive sources of nitro- 
gen, carbon or other mineral salts or vitamins, because these substrates have quite a complex composition, containing several nutrients. These complex substrates may cause a positive effect on lipase production when individually analyzed. However, the use of both of them simultaneously can cause an excess in some of these important nutrients and a consequent unwanted inhibition in enzyme production.

The lipase in the crude enzymatic extract obtained using the conventional medium presented optimal temperature and $\mathrm{pH}$ around $30^{\circ} \mathrm{C}$ and 7.0 , respectively. The lipase produced in the industrial medium had optimal temperature and $\mathrm{pH}$ of $37^{\circ} \mathrm{C}$ and $\mathrm{pH} 7.0$, respectively.

\section{Acknowledgments}

The authors would like to thank CNPq, CAPES and Intecnial SA for the financial support and scholarships.

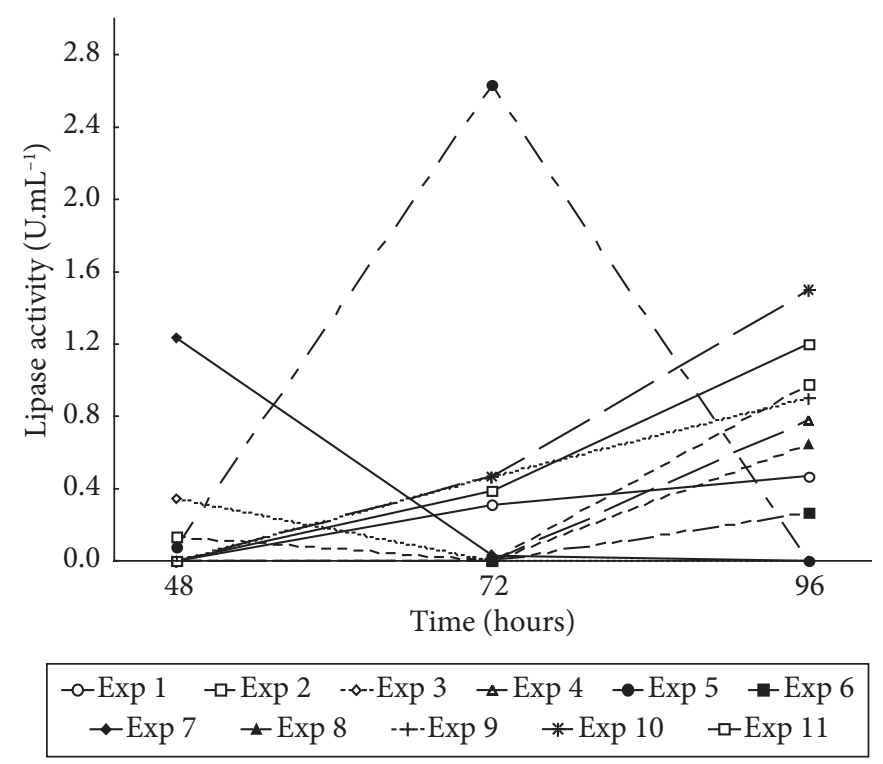

Figure 2. Kinetics of submerged fermentation for lipase production using the industrial medium: full $2^{3}$ experimental design.

\section{References}

ABBAS, $H$. et al. Isolation and characterization of an extracellular lipase from Mucor strain isolated from palm fruit. Enzyme and Microbial Technology, Atlanta, v. 31, n. 7, p. 968-978, 2002.

BENJAMIN, S.; PANDEY, A. Optimization of liquid media for lipase production by Candida rugosa. Bioresource Technology, Orlando, v. 55, n. 2, p. 167-170, 1995.

. Isolation and characterization of three distinct forms of lipases from Candida rugosa produced in solid state fermentation. Brazilian Archives of Biology and Technology, Curitiba, v. 44, n. 2, p. 213-221, 2001.

BURKeRT, J. F. M. Otimização das Condições de Produção da Lipase por Geotrichum candidum NRRL-Y552. Campinas, 2002. Tese (Doutorado em Engenharia de Alimentos), Departamento de Engenharia de Alimentos, Universidade Estadual de Campinas - UNICAMP.

BURKERT, J. F. M.; MAUGERI, F.; RODRIGUES, M. I. Optimization of extracellular lipase production by Geotrichum sp. using factorial design. Bioresource Technology, Orlando, v. 91, n. 1, p. 77-84, 2004.

CASTILHO, L. R. et al. Economic analysis of lipase production by Penicillium restrictum in solid state and submerged fermentations. Biochemical Engineering Journal, Manchester, v. 4, n. 3, p. 239-247, 2000.

ELLAIAH, P. et al. Production of lipase by immobilized cells Aspergilus niger. Process Biochemistry, Nancy, v. 39, n. 5, p. 525-528, 2004.

FADILOGLU, S.; SOYLEMEZ, Z. Kinetics of lipase-catalyzed hydrolysis of olive oil. Food Research International, Ontario, v. 30, n. 2, p. 171-175, 1997.

FREIRE, D. M. et al. Lipase production by Peniillium restrictum in a bench-scale fermenter: effect of carbon and nitrogen nutrition, agitation, and aeration. Applied Biochemistry and Biotechnology, California, v. 63, n. 4, p. 63-65, 1997.

FREIRE, D.M.G. Seleção de Microrganismos lipolíticos e estudo da produção de lipase por Penicillium restrictum. Rio de Janeiro, 1996. Tese (Doutorado em Bioquímica), Instituto de Química, Universidade Federal do Rio de Janeiro - UFRJ.

HASAN, F.; SHAH, A. A.; HAMEED, A. Industrial applications of microbial lipases. Enzyme and Microbial Technology, Atlanta, v. 39, n. 2, p. 235-251, 2006.

Table 9. Matrix of the complete experimental design for the evaluation of the optimal temperature and $\mathrm{pH}$ (coded and real values) with the response lipase activity for submerged fermentation in conventional and industrial media.

\begin{tabular}{|c|c|c|c|c|}
\hline \multirow[t]{2}{*}{ Experiment } & \multirow[t]{2}{*}{$\mathrm{pH}$} & \multirow[t]{2}{*}{ Temperature $\left({ }^{\circ} \mathrm{C}\right)$} & \multicolumn{2}{|c|}{ Lipase activity $\left(\mathrm{U}_{\mathrm{mL}} \mathrm{mL}^{-1}\right)$} \\
\hline & & & Synthetic medium & Industrial medium \\
\hline 1 & $-1(5.5)$ & $-1(32)$ & 0.69 & 1.76 \\
\hline 2 & $-1(5.5)$ & $1(42)$ & 1.92 & 0.4 \\
\hline 4 & $1(8.5)$ & $1(42)$ & 4.02 & 0 \\
\hline 5 & $0(7.0)$ & $-1.41(29.95)$ & 4.37 & 0 \\
\hline 8 & $1.41(9.11)$ & $0(37)$ & 2.34 & 1.6 \\
\hline $9^{*}$ & $0(7.0)$ & $0(37)$ & 2.72 & 1.6 \\
\hline $10^{*}$ & $0(7.0)$ & $0(37)$ & 2.42 & 1.92 \\
\hline $11^{*}$ & $0(7.0)$ & $0(37)$ & 2.53 & 1.76 \\
\hline
\end{tabular}

${ }^{\star}$ Central point. 
HOUDE, A.; KADEMI, A.; LEBLANC, D. Lipases and their industrial applications: an overwiew. Applied Biochemistry and Biotechnology, California, v. 3, n. 6, p. 118-125, 2004.

JAEGER, K. E.; REETZ, M. T. Microbial lipases from versatile tools for biotechnology. Trends in Biotechnology, Warwick, v. 16, n. 9, p. 396-403, 1998.

KAMINI, N. R.; MALA, J. G. S.; PUVANAKRISHNAN, D. Lipase production from Aspergillus niger by solid-state fermentation using gingelly oil cake. Process Biochemistry, Nancy, v. 33, n. 5, p. 505-511, 1998.

KOLOSSVÁRY, G. J. Optimization of lipase activity from Rhizopus sp. in trigliceride hydrolysis using a modified simplex method. Process Biochemistry, Nancy, v. 31, n. 5, p. 595-600, 1996.

MAHADIK, N. D. et al. Production of acidic lipase by a mutant Aspergillus niger NCIM 1207 in submerged fermentation. Process Biochemistry, Nancy, v. 39, n. 12, p. 2031-2034, 2004.

MAIA, M. M. D. et al. Effect of culture conditions on lipase production by Fusarium solani in batch fermentation. Bioresource Technology, Orlando, v. 76, n. 1, p. 23-27, 2001.

MARTINS, T. S. Produção e purificação de lipases de Yarrowia lipolytica IMUFRJ 50682. Rio de Janeiro, 2001. Dissertação
(Mestrado em Ciências da Saúde), Universidade Federal do Rio de Janeiro.

PASTORE, G. M.; DA COSTA, V. S. R.; KOBLITZ, M. G. B. Purificação parcial e caracterização de lipase extracelular produzida por nova linhagem de Rhizopus sp. Ciência e Tecnologia de Alimentos, Campinas, v. 23, n. 2, p. 135-140, 2003.

PUTHLI, M. S.; RATHOD, V. K.; PANDIT, A. B. Optimization of lipase production in a triple impeller bioreactor. Biochemical Engineering Journal, Manchester, v. 27, n. 3, p. 287-294, 2006.

SHU, C.; XU, C.; LIN, G. Purification and partial characterization of a lipase from Antrodia cinnamomea. Process Biochemistry, Nancy, v. 41, n. 3, p. 734-738, 2006.

SNELLMAN, E. A.; SUlLIVAN, E. R.; COLWELL, R. R. Purification and properties of the extracellular lipase, LipA, of Acinetobacter sp. Biochemical Engineering Journal, Manchester, v. 11, n. 2, p. 269-274, 2002.

TAN, T. et al. Screening of high lipase producing Candida sp. and production of lipase by fermentation. Process Biochemistry, Nancy, v. 39, n. 4, p. 459-465, 2003.

VARGAS, G. D. L. P. Estudo da produção de lipase por Penicillium simplicissimum utilizando torta de soja como substrato. Erechim, 2004. Dissertação (Mestrado em Ciências Agrárias), Departamento de Ciências Agrárias, Universidade Regional Integrada. 